Volume 5 Number 1 April 2019 page 26-38

p-ISSN:2460-1497 and e-ISSN: 2477-3840

DOI: https://doi.org/10.26858/est.v5i1.7852

\title{
The Use Of 3CM (Cool-Critical-Creative-Meaningful) Model In Blended \\ Learning To Improve Creative Thinking Ability \\ In Solving Mathematics Problem
}

\author{
Wahyudi $^{1}$, Budi Waluya ${ }^{2}$, Hardi Suyitno ${ }^{3}$, Isnarto ${ }^{4}$ \\ ${ }^{1}$ Mathematics education, Univesitas Kristen Satya Wacana, Indonesia \\ Email: yudhi@staff.uksw.edu \\ ${ }^{2}$ Mathematics education, Univesitas Negeri Semarang, Indonesia \\ Email: s.b.waluya@mail.unnes.ac.id \\ ${ }^{3}$ Mathematics education, Univesitas Negeri Semarang, Indonesia \\ Email: hardi.suyitno@mail.unnes.ac.id \\ ${ }^{4}$ Mathematics education, Univesitas Negeri Semarang, Indonesia \\ Email: isnarto@mail.unnes.ac.id
}

(Received: December-2018; Reviewed: February-2019; Accepted: March-2019; Published: April-2019)

(7) (2) 92019 - EST Graduate Program Universitas Negeri Makassar. This is an article with open access under license CC BY-NC-4.0 (https://creativecommons.org/licenses/by-nc/4.0/ ).

\begin{abstract}
This study aims to describe and test the effectiveness of $3 C M$ learning model with blended learning to improve students' creative thinking ability in solving mathematic problems. A pre experimental design with one group pre-test post-test design pattern was applied in this study. Creative thinking ability is measured by test technique and then in triangulation with observation and interview. Students were given a test, observed when solving the problem, and interviewed based on the answers given. To see the effectiveness of 3CM learning with blended learning done with paired $T$ test with assisted with SPSS program then triangulated with observation and interview. Based on the test results, it obtained the average pre-test 60.51 and post-test 75.96. Result of paired T tests, test got sig value. (2-tailed) 0.000 means there was a significant difference between pre-test and post-test results. It indicated that 3CM learning with blended learning effectively improves students' creative thinking ability in solving problems. This happened because learning gives students the opportunity to think systematically by beginning by criticizing the interesting contextual problems and ending with meaningful reflection with adequate learning resources both when face-to-face and online.
\end{abstract}

Keywords: 3CM model, blended learning, creative thinking ability, problem solving

\section{INTRODUCTION}

One of the goals of Indonesian education is to develop the potential of learners to become creative human beings (Law No. 20 of 2003). In fact, this is one of the reasons for the change of Indonesian national curriculum from KTSP into the 2013 curriculum to form creative learners. Creative is the highest level of competence in Bloom's latest taxonomy (Stanny, 2016). Creative not only in producing products, but creative in thinking, including mathematical creative thinking. The ability to think creatively grows from one's creativity. Creativity arises also because of the opportunity to do so.
Creative is also one of the main components in 21st century education (Mann, 2006; Tindowen, Bassig, \& Cagebas, 2017). Therefore, the content-exporter curriculum emphasises the development of creative thinking skills for learners (Vale \& Barbosa, 2015; Sternberg, 2006). Creative thinking skills will produce creativity that leads to the acquisition of new insights, new approaches, new perspectives, or new ways of understanding issues that include aspects of flexibility, novelty, and elaboration.

Creativity of learners into something that needs to be grown in education, including in elementary school (SD) through the process of 
creative thinking. Where creativity is the quality of integration of someone who becomes a person's capital to work (Khairullina, N., Bakhtizin, R., et.al. 2016). Creativity arises also because of the opportunity to do so. Creativity applies to all areas of learning including in the field of mathematics In addition, the ability to think creatively is also a benchmark for the success of learners in learning (Mairing, 2016).

Real problems in learning, not all mathematics learning in schools provide opportunities for learners to develop creative thinking skills included in the mathematics field. More learning is oriented towards the amount of material given and the acquisition of academic value that focuses on cognitive abilities. Learning only in order to achieve the target test scores and less to give learners experience to think, logical reason and solving problems (Rachmawati, 2012). This condition also occurs in learning mathematics in colleges including prospective teachers. Mathematics learning has not given students the opportunity to improve their ability to have a logical reason and creative thinking in solving problems (Suarma \& Kusumah, 2016; Wahyudi, W., Waluya, S.B. \& Rochmad, R., 2018). This situation ultimately affects the pattern of learning as they become teachers and teach in school. This type of learning does not provide enough space for students to develop their creative thinking skills including in math learning. Math learning becomes a memorizing activity so that the opportunity to think becomes a habit that is far from the learners.

Mathematics often becomes less interesting information that is simply forgotten, does not last long in the student's brain. It is necessary to change the paradigm of learning mathematics is a fun learning mathematics and gives students the opportunity to think with contextual issues to be easily understood. Learning mathematics should be accordance with the reality context of student life, so that math is easy to remember, imagine, represented, manipulated and assembled cognitive maps in a good schemata (Wahyudi, W., Waluya, S.B. \& Rochmad, R., 2017). This is consistent with today's mathematical learning paradigm, where mathematics is close to humans, mathematics is a part of human culture (Hersh, 1997; Siswono, 2007; Rachmawati, 2012) and is part of social reality (Ernest in Hersh, 1997; Zevenbergen, 2004). The results of the study (Wahyudi, W., Waluya, S.B. \& Rochmad, R., 2018) also support this condition, scaffolding in an interesting and correct way and using contextual problems can provide motivation for students to want to learn math and be able to solve math problems. Interviews show motivating with interesting, contextual, easy to imagine, not always formulas and numbers, getting them interested and willing to learn math. Once they are comfortable, their concept can begin to build although not the same speed depending on the subject's response to receive scaffolding.

In addition has to be contextual, the language aspect becomes something that is very important in learning mathematics. Because the wrong language will give the wrong understanding, for example the mistake of learners in interpreting the word in the matter. Not because they do not know the problem because inappropriate language will make different interpretation to what the teacher wants. So the process of mathematical communication in this case do not work well (Zevenbergen, 2004; Orton, 2004; Hudojo, 1988; Anthony \& Walshaw, 2009). Good language will make mathematics become interesting information, easy to remember and stored long in the learner learners with a true and stable schemata. The schemata will be utilized to solve the given problem. Someone takes advantage of memory, representation and manipulation to solve a given mathematical problem. This ability is called problem-solving ability (Matlin, 2009).

These results serve as a further step to formulate how mathematics learning can provide opportunities for students to develop creative thinking skills in the field of mathematics in a cool and fun way, easy to remember as a good memory, but give their critical expression and creative thinking and give meaning in their life. So that required the design of learning with the study of the right theory in the hope can provide a cool learning atmosphere as well as the opportunity to think critically, creatively and meaningfully. Learning should provide a memorable experience and opportunities learners utilize the left and right brain in the cool activities, critical, creative, and meaningful that named with 3CM Learning. This learning model adopts and combines contextual learning, realistic mathematics, and meaningful learning of Brownell and David Ausubel. Learning begins with the giving of contextual problems close to the activities, culture and social reality of human beings so 
that it becomes a memorable, imaginary, represented and manipulated experience in the student's cognitive map. The hope makes it easier for students to learn mathematics without having burdened with so many mathematical formulas. Learning will provide a balance between the cognitive and the feelings aspects. This will provide a balance between the leftbrain work (logic source) and the right brain (the source of spiritual feeling) (Nurhalim, 2003). Feelings are one component of creative thinking ability (creativity). With this balance will be formed prospective teachers who have the ability to think creatively good. The ability to think creatively is a combination of logical thinking and diverging thinking. When a person applies his creative thinking ability to solve problems, then divergent thinking skills will generate new ideas or ideas to solve problems. While the ability to think logically involves a rational and systematic process to examine and validate the conclusions of the resulting problem solving (Siswono, 2010).

Besides, it is necessary to have wide learning rides for students to find information related to problem solving, from fluency, flexibility, originality, and elaboration aspects from many sources. This can be done by utilising technology as a learning tool and learning resource. To package this kind of learning model requires special skills for a teacher. Not enough content, or pedagogical learning skills, but should be able to combine the two. Not only required a special ability that is the use of technology in learning (technological). By combining these three abilities then the classroom learning will be more interesting, efficient and meaningful for the students. Learning is packaged in face-toface and online learning (blended learning). This lesson will give students the opportunity to look for problem solving information provided with creative new solutions. With this learning process will provide opportunities for learners to get many resources and a lot of learning from others to inspire them in solving the problems given.

\section{METHOD}

Pre experimental design with one group pre test and post test design pattern was applied in this study. One class was conducted as experimental class to be given learning with $3 \mathrm{CM}$ learning model. Before studying with $3 \mathrm{CM}$ learning model, students were given pretest to see their initial ability. After following the learning, students were given post test to see the impact of 3CM learning. The effectiveness of 3CM learning model could be seen from the average difference of pretest and post test results.

Students of Study Program of Primary School Teacher Education class of 2017 as the population in this research. The sample were taken by random sampling technique, with given lottery to representation of 7 existing classes, selected class A as sample of research.

The data were collected using test, observation, and interview techniques. The test was used to measure the creative thinking ability and the results were compared and analysed using SPSS through Paired samples T-test. Guidelines for the assessment and scoring of creative thinking skills were undertaken with the provisions as in Table 1 and Table 2 below.

Table 1. Description of Aspects of Creative Thinking Skills

\begin{tabular}{|c|c|c|}
\hline Aspect & Description & Explanation \\
\hline Fluency & $\begin{array}{l}\text { The ability of students to generate many } \\
\text { ideas of true value in a short time }\end{array}$ & $\begin{array}{l}\text { Judging from the idea / idea of the answer and the } \\
\text { number of ideas / ideas of the right answers are } \\
\text { generated }\end{array}$ \\
\hline Flexibility & $\begin{array}{l}\text { The ability of students to produce many } \\
\text { categories of answers that are true value }\end{array}$ & $\begin{array}{l}\text { Viewed from the student's correct answers and } \\
\text { explored in depth in interviews and discussions so } \\
\text { to elicit another idea / another way to check again } \\
\text { the correct answer given }\end{array}$ \\
\hline Novelty & $\begin{array}{l}\text { Students' ability to use new / unique, or } \\
\text { unusual strategies / answers (different } \\
\text { from other students) to solve problems } \\
\text { and be true }\end{array}$ & $\begin{array}{l}\text { Viewed from student answers and compared with } \\
\text { other student's answers to see new things different } \\
\text { from other friends as well as deeply dug in the } \\
\text { interview. }\end{array}$ \\
\hline
\end{tabular}




\begin{tabular}{cll}
\hline Aspect & \multicolumn{1}{c}{ Description } & \multicolumn{1}{c}{ Explanation } \\
\hline Elaboration & $\begin{array}{l}\text { The ability of students to explain in } \\
\text { detail, coherent, and coherent to certain } \\
\text { mathematical procedures, answers, or } \\
\text { mathematical situations as a solution to } \\
\text { the correct problem that he gave }\end{array}$ & $\begin{array}{l}\text { Judging from the explanation of the correct answers } \\
\text { given and explored in depth through interviews and } \\
\text { discussions }\end{array}$ \\
\hline
\end{tabular}

Table 2. Screening Guidelines for Thinking Ability of Mathematical Creative Thinking

\begin{tabular}{|c|c|c|}
\hline $\begin{array}{l}\text { Measured } \\
\text { Aspects }\end{array}$ & Subject Response to Problems or Problems & Score \\
\hline \multirow{5}{*}{ Fluency } & Not answering or giving wrong answers & 0 \\
\hline & Provide ideas that are not relevant to problem solving & 1 \\
\hline & Gives relevant ideas but the answer is wrong & 2 \\
\hline & Gives more than one relevant answer idea but the final result is still wrong & 3 \\
\hline & Provide more than one idea of answer that is relevant to the final result is correct & 4 \\
\hline \multirow{5}{*}{ Flexibility } & Not answering or giving wrong answers & 0 \\
\hline & Gives one answer category but the final result is wrong & 1 \\
\hline & Gives one category of answers and the final result is correct & 2 \\
\hline & $\begin{array}{l}\text { Giving more than one category of answers but the final result is wrong because } \\
\text { there are errors in the calculation process }\end{array}$ & 3 \\
\hline & $\begin{array}{l}\text { Giving more than one category of answers, the calculation process and the final } \\
\text { result are correct }\end{array}$ & 4 \\
\hline \multirow{5}{*}{ Novelty } & Not answering or giving wrong answers & 0 \\
\hline & Give answers in its own way but can not be understood & 1 \\
\hline & $\begin{array}{l}\text { Giving the answer in its own way, the calculation process is directed but not } \\
\text { finished getting the right result }\end{array}$ & 2 \\
\hline & $\begin{array}{l}\text { Providing answers in its own way but there are errors in the calculation process at } \\
\text { the end of the answer so the final result is wrong }\end{array}$ & 3 \\
\hline & Giving answers in its own way, the calculation and the results are correct & 4 \\
\hline \multirow{5}{*}{ Elaboration } & Not answering or giving wrong answers & 0 \\
\hline & Give unspecified answers and wrong results & 1 \\
\hline & Giving an answer is not detailed but the final result is correct & 2 \\
\hline & Gives detailed answers coherent, and coherent but the final result is wrong & 3 \\
\hline & Provide detailed, coherent, and coherent answers and the final result is correct & 4 \\
\hline
\end{tabular}

Observation and interview techniques were applied to strengthen the test results data to obtain accurate and complete data.

Data analysis techniques to see the effectiveness of 3CM learning model was done by comparing the results of pretest and post test creative thinking ability. Pre test and post test results were analysed, classified and compared using Paired samples T-test with SPSS program.

Data of initial ability of mathematical creative thinking was classified based on the creative thinking level. (Creative Thinking Level) CTL 3 (Creative), CTL 2 (Creative Enough), CTL 1 (Less Creative), CTL (Creative Creativity), Creative Thinking Level (CTL), and
CTL 0 (Not Creative). Criteria for mathematical creative thinking level according to Table 3.

Table 3. Category determination the level of creative thinking skills

\begin{tabular}{ccc}
\hline Interval & $\begin{array}{c}\text { Creative Thinking } \\
\text { Level }(\text { CTL) }\end{array}$ & Category \\
\hline $78-100$ & CTL 3 & Creative \\
$52-77$ & CTL 2 & Creative Enough \\
$26-51$ & CTL 1 & Less Creative \\
$0-25$ & CTL 0 & Not Creative
\end{tabular}




\section{RESULT AND DISCUSSION}

\section{Result}

Before having the test, the students got the learning with $3 \mathrm{CM}$ learning model for 10 weeks (10 meetings). The learning process was done face-to-face and online. Implementation of $3 \mathrm{CM}$ learning was done in seven steps of learning (syntax) which were, motivation, contextual problem, critical issue, problem solving, concept implementation in creative product, confirmation, reflection. Based on these 7 steps

of learning, it could be mapped according to the nature of 3CM learning in Table 4 below.

Table 4. Aspects in 3CM learning model

\begin{tabular}{|c|c|c|}
\hline Aspect & Learning Syntax & Explanation \\
\hline Cool & $\begin{array}{l}\text { 1. Motivation } \\
\text { 2. Contextual Problems }\end{array}$ & $\begin{array}{l}\text { Plays a significant role in motivating the students by giving } \\
\text { contextual problems in an enjoyable learning atmosphere. This } \\
\text { initial stage enables the students to criticise the contextual problems } \\
\text { given. }\end{array}$ \\
\hline Critical & $\begin{array}{l}\text { 3. Criticize the } \\
\text { Contextual Issues } \\
\text { 4. Troubleshooting }\end{array}$ & $\begin{array}{l}\text { Students are asked to provide the solutions from the contextual } \\
\text { problems given by criticising them first. }\end{array}$ \\
\hline Creative & $\begin{array}{l}\text { 5. Implementation of } \\
\text { concepts in creative } \\
\text { products }\end{array}$ & $\begin{array}{l}\text { Students are expected to think about the potential creative product } \\
\text { that might be produced as the implementation of the previous } \\
\text { concept. }\end{array}$ \\
\hline Meaningfull & $\begin{array}{l}\text { 5. Confirmation } \\
\text { 6. Reflection }\end{array}$ & $\begin{array}{l}\text { Teacher and students discuss the result in order to give meaning } \\
\text { from the lesson learned and make a decision in implementing the } \\
\text { concept in the real life. }\end{array}$ \\
\hline
\end{tabular}

Before and after learning in 3CM learning models, students were given pretest and post test to gain initial ability and end-ability in their creative thinking. Pretest and post test results of students' creative thinking ability can be seen in Table 5, Table 6 and Table 7 below. Based on the data in Table 5, the mean of pretest and post test results are 60.52 and 75.96 with the standard deviation of pretest results of 9.60 and post test 6.36 with the standard of precast error 1.85 and post test 1.22 . These results indicate that the creative thinking ability of post test results closer to the mean grade compared with the pretest results. Thus, the value of post test variation is smaller than the pretest results seen from the mean value (mean).

Table 5. Description of Pre-test and Post-test

\begin{tabular}{lcc}
\hline Category & Pre Test & Post Test \\
\hline Mean & 60.52 & 75.96 \\
Minimum & 45.00 & 68.00 \\
Maximum & 80.00 & 90.00 \\
Std. Error & 1.85 & 1.22 \\
\hline
\end{tabular}

Table 6. The Result of the Category and Classified Pre-test of Students' Creative Thinking Ability

\begin{tabular}{ccccc}
\hline Interval & Total & Percentage & $\begin{array}{c}\text { Creative Thinking } \\
\text { Level (CTL) }\end{array}$ & Category \\
\hline $78-100$ & 2 & 7.41 & CTL 3 & Creative \\
$52-77$ & 19 & 70.37 & CTL 2 & Creative Enough \\
$26-51$ & 6 & 22.22 & CTL 1 & Less Creative \\
$0-25$ & 0 & 0 & CTL 0 & Not Creative \\
Total & 27 & 100 & & \\
Average & 60.52 & & & \\
\hline
\end{tabular}


Pre test data shows that, students' initial ability before following learning with $3 \mathrm{CM}$ learning model is in medium and low category that is $92,59 \%$ ( 25 people from 27 people). Only
$7.41 \%$ (2 people) are in creative category. This result shows that students' creative thinking ability still needs improvement.

Table 7. The Result of the Category and Classified Post-test of Students' Creative Thinking Ability

\begin{tabular}{ccccc}
\hline Interval & Total & Percentage & $\begin{array}{c}\text { Creative Thinking Level } \\
\text { (CTL) }\end{array}$ & Category \\
\hline $78-100$ & 11 & 40.74 & CTL 3 & Creative \\
$52-77$ & 16 & 59.26 & CTL 2 & Creative \\
Enough \\
$26-51$ & 0 & 0 & CTL 1 & Less Creative \\
$0-25$ & 0 & 0 & CTL 0 & Not Creative \\
Total & 27 & 100 & & \\
Average & 75.96 & & & \\
\hline
\end{tabular}

After following the 3CM learning method, there was an increasing number of students, who had creative and medium category. The creative category improvement raised from $7.41 \%$ ( 2 people) to $40.74 \%$ (11 people). The number of students with moderate and weak categories decreased from $92.59 \%$ (25 people) decreased to $59.26 \%$ (16 people). This shows an increasing numbers in creative thinking ability before and after following the learning with $3 \mathrm{CM}$ learning.

This result was supported by observations when they were working on test questions. Students worked on the problem independently with the stages of solving the problems that had been directed and produce several solutions, although not yet according to aspects of creative thinking could be implemented optimally. Descriptions of observation results can be seen in Table 8 below.

To see further the impact of the application of $3 \mathrm{CM}$ learning in learning it is necessary to test the effectiveness of the model by using paired $\mathrm{T}$ tests. This was chosen because the study design used a quasi-experiment with one group pretest post test design. There is a disadvantage of this design because it uses only one class. Here are the results of paired T tests that begin with the normality test data as shown in Table 9 and Table 10 below.

Table 8. Observation Results of Student Activities When Working on Tests

\begin{tabular}{lccc}
\hline CTL Aspect & \multicolumn{3}{c}{ Questions } \\
& $\mathbf{1}$ & $\mathbf{2}$ & $\mathbf{3}$ \\
\hline Fluency & 20 & 20 & 22 \\
Flexibility & 18 & 16 & 15 \\
Novelty & 12 & 13 & 11 \\
Elaboration & 11 & 11 & 12 \\
\hline
\end{tabular}


Table 9. The Result of the Normality Test of Creative Thinking Skills Pre-test and Post-test

\begin{tabular}{lcccccc}
\hline & \multicolumn{2}{c}{ Kolmogorov-Smirnova } & \multicolumn{3}{c}{ Shapiro-Wilk } \\
\cline { 2 - 7 } & Statistic & df & Sig. & Statistic & df & Sig. \\
\hline Pre Test & .145 & 27 & .150 & .930 & 27 & .068 \\
Post Test & .153 & 27 & .107 & .932 & 27 & .077
\end{tabular}

a. Lilliefors Significance Correction

There were only 27 students taken as a sample. Hence, the results of normality taken was the result of normality with Shapiro-Wilk. According to the data in Table 7, the Sig value could be obtained. Pre test and Post test of 0.068 and 0.077 are both greater than 0.05 so that both data are normally distributed. This result was a requirement for the following steps: Paired Samples $\mathrm{T}$ Test. The results obtained can be seen in Table 10 below.
Table 10. Test Result of Paired Samples T-Test Creative Thinking Ability

\begin{tabular}{|c|c|c|c|c|}
\hline \multicolumn{5}{|c|}{ Paired Samples Correlations } \\
\hline & & $\mathrm{N}$ & Correlation & Sig. \\
\hline Pair 1 & $\begin{array}{l}\text { Pre Test \& } \\
\text { Post Test }\end{array}$ & 27 & .777 & .000 \\
\hline
\end{tabular}

Table 11. Test Result of Paired Samples T-test Creative Thinking Ability

\begin{tabular}{|c|c|c|c|c|c|c|c|c|c|}
\hline & & \multicolumn{5}{|c|}{ Paired Differences } & \multirow{3}{*}{$\mathbf{t}$} & \multirow{3}{*}{ df } & \multirow{3}{*}{$\begin{array}{l}\text { Sig. (2- } \\
\text { tailed) }\end{array}$} \\
\hline & & \multirow[t]{2}{*}{ Mean } & \multirow[t]{2}{*}{$\begin{array}{c}\text { Std. } \\
\text { Deviation }\end{array}$} & \multirow[t]{2}{*}{$\begin{array}{l}\text { Std. } \\
\text { Error } \\
\text { Mean }\end{array}$} & \multicolumn{2}{|c|}{$\begin{array}{c}95 \% \\
\text { Confidence } \\
\text { Interval of the } \\
\text { Difference }\end{array}$} & & & \\
\hline & & & & & Lower & Upper & & & \\
\hline Pair 1 & $\begin{array}{l}\text { Pre Test - } \\
\text { Post Test }\end{array}$ & -15.44 & 6.14 & 1.182 & -17.87 & -13.01 & -13.06 & 26 & .000 \\
\hline
\end{tabular}

Based on data of Table 10 and Table 11 it is found that the value of sig. $0.000<0.05$ and $t$ arithmetic (13.06)> t table (2.05). It was found that there are significant differences between pretest and post test results. Where post test results were better than the pretest results. Thus, it could be concluded that the application of 3CM learning is effective in improving students' creative thinking skills in solving math problems.

\section{Discussions}

Based on the results of data analysis and hypothesis testing, it found that the $3 \mathrm{CM}$ learning model with blended learning could improve students' creative thinking skills in solving mathematical problems. This happened because the learning situation was prepared and implemented in accordance with the context of student life, and in fun activities package. According to the current paradigm of learning mathematics, where mathematics is close to humans, mathematics is part of human culture (Hersh, 1997; Siswono, 2007; Rachmawati, 2012) and part of social reality (Ernest in Hersh, 1997; Zevenbergen, 2004). In line with the current study (Author, 2018), learning with scaffolding in an interesting and correct way and using contextual problems could motivate students to want to learn mathematics and they would be able to solve mathematical problems. The interview results showed motivating with interesting, contextual, easy to imagine things, not always in the form of formulas and numbers, 
making them interested and willing to learn mathematics.

One example when they learn to determine the circumference of a circle by playing Phi $((\pi)$. The activity begins (the first stage of 3CM learning) with a story played by students with funny scenes with mixed Javanese language. The story tells about siblings who on the way and talked about mathematic that discussing Phi $(\pi)$ and its relationship to the circle, which can be seen from Figure 1 below.



Figure 1. Story as a contextual problem

To be able to criticise the problem, each group looks at animations that have been prepared by the lecturers who are shared in the WhatsApp class (download animation). With the help of the animation that was prepared finally, the student was able to criticise and find out what Phi was $(\pi)$ and its relationship to the circumference, diameter, and radius of the circle.

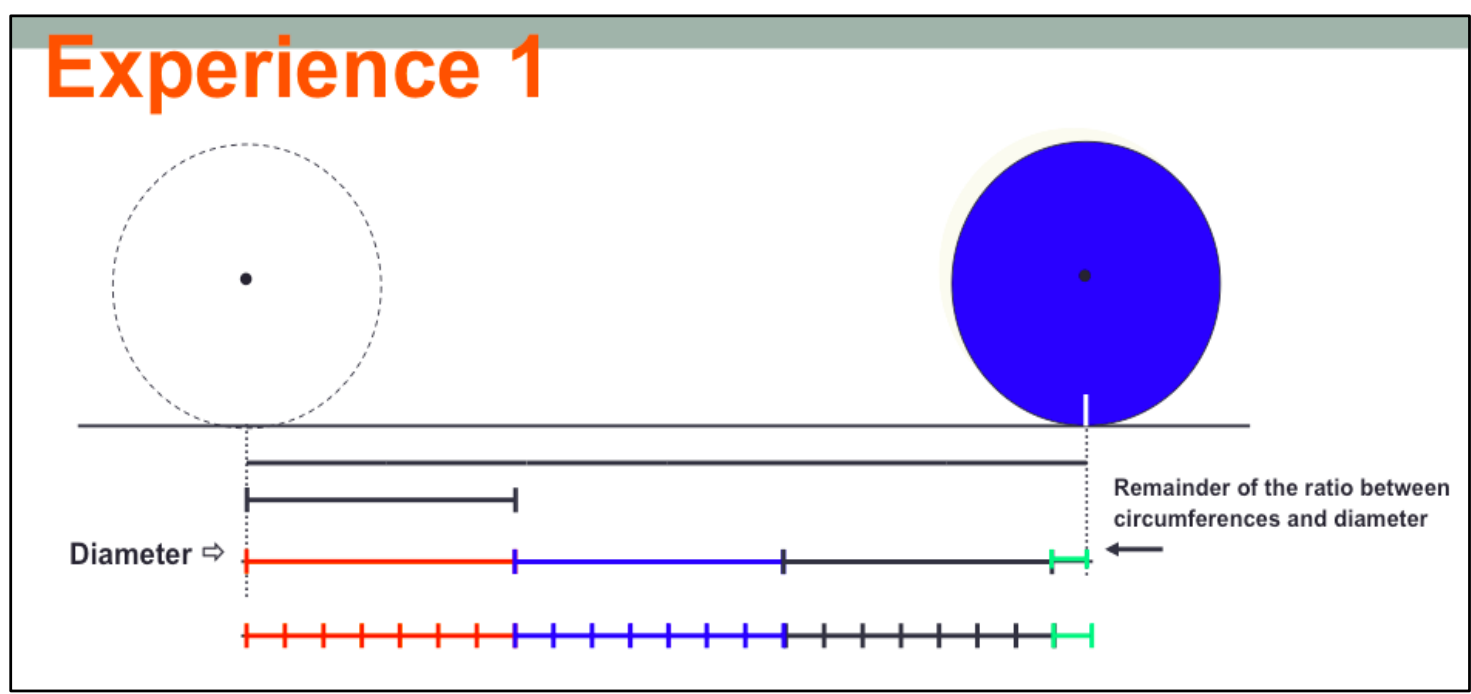

Figure 2. Animation of Phi and around the circle 


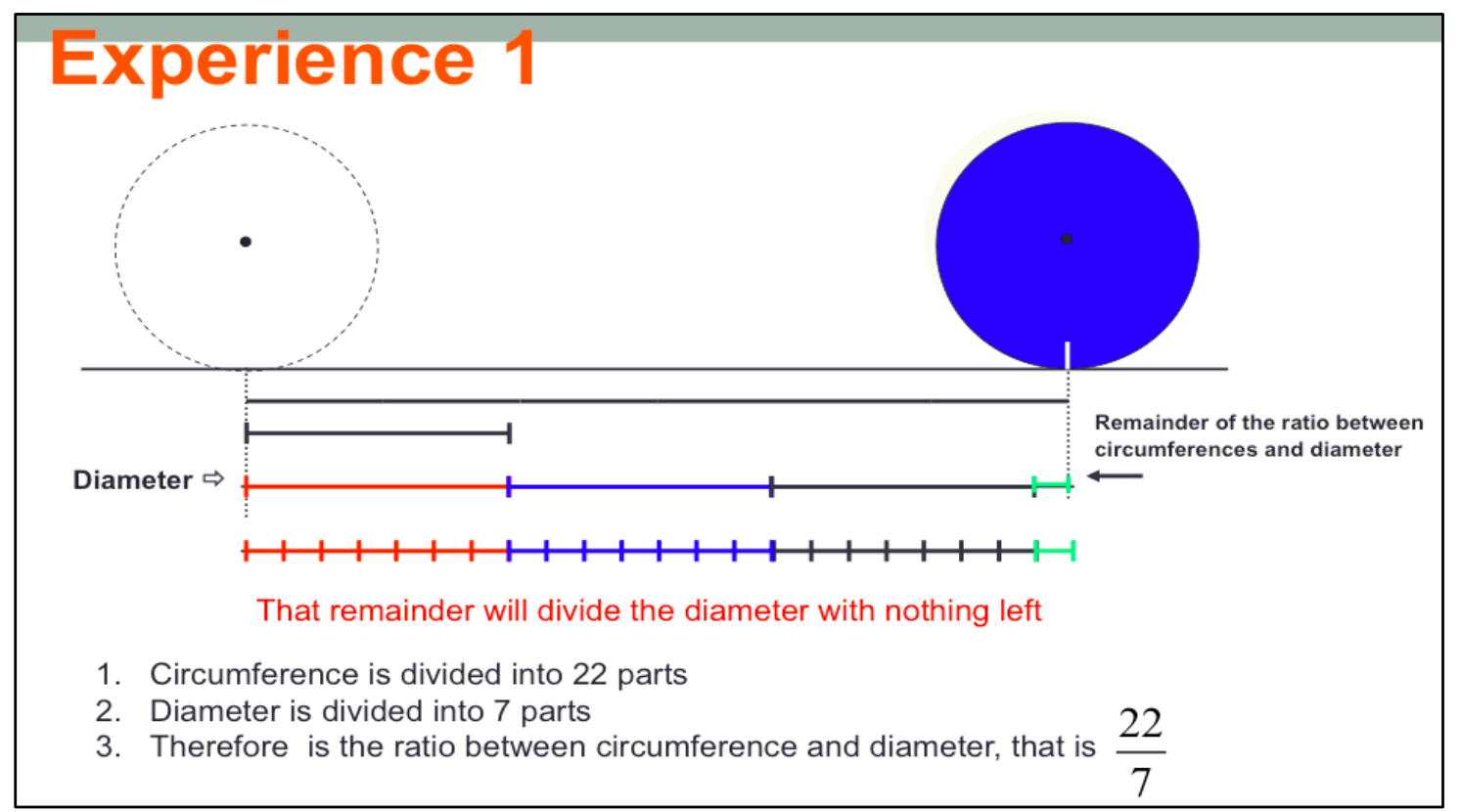

Figure 3. Animation of Phi and around the circle

The next step was that students in the group criticise the questions given by the lecturer regarding the application of the traveling concept in the working system of the gears on the bicycle and the implications for the number of wheel turns and the distance traveled by the bicycle. The experience of criticising this question enabled the students to apply the concept of traveling in everyday life.

The third stage of 3CM learning is Creative that produces creative products / thoughts from concepts that have been learned. The task given was to make math problem solving stories related to the circumference of the circle in the form of power points and presented in class. This task was carried out in groups.

The fourth step of 3CM learning is taking meaning from learning (meaningful). This stage focuses more on confirmation and reflection. The results of the presentation and group discussions were confirmed together to identify how many questions were generated by each group and the quality of the questions and how the solution was to solve the problems that had been made by each group. Based on the questions made and the results of the discussion, lecturers and students formulated the linkages between the concepts learned with their lives and the benefits derived from the concepts. With this learning pattern, students could learn from the reality of their lives, activities that hold with them and take advantage of them for their lives. In this way, they were easier to understand mathematical concepts because the event was close to them.

In addition, students could also experience directly through contextual events, students also could get experience in online learning that had been prepared. Learning could be accessed at http://flearn.uksw.edu in mathematics problem solving courses. One of the online activities conducted by students as shown in Figure 4 below. 


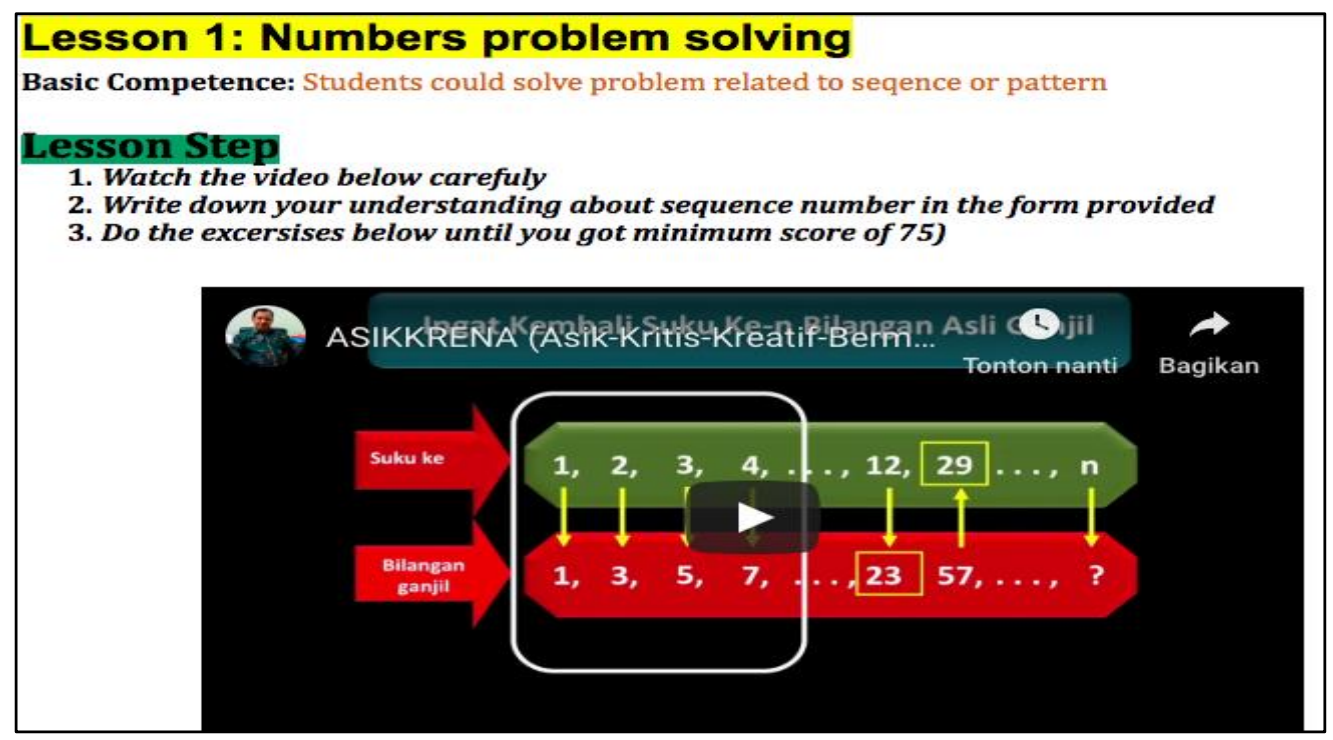

Figure 4. Example of Online Class Display

After students look at the problem of fiber criticizing the problems contained in the video that has been given, students created creative products as stated in the form provided that produced creative works in the form of power point animations for even number patterns (here is the link to the creative work form: click here). This condition provided opportunities for students to have enough vehicles as learning resources that as accessible whenever and wherever they like. In addition, this model allows students to see creative and unusual problem-solving ways with interesting approaches to inspire them to produce problem solving in new ways. This is in accordance with the principle of creativity arising because there is an opportunity. There are $3 \mathrm{~N}$ activities (Niteni, Nerokke, Nambahi) taught by Ki Hajar Dewentara. This concept makes the thought that creativity will emerge if students are given the opportunity. The creativity that appears is still at a level that must see the example first. The results of the interview supported this statement, students at the initial level tend to mimic so that raises ideas to think about other creative works. In line with Hsieh's (2011), the teaching style of a teacher can influence students' learning reflections (in this case student). Therefore, if the teachers want to produce creative students, they must be creative first in designing and implementing learning. As supported by Morais \& Azevedo (2011), a good teacher must be creative so that it can be an example for students to create further. In addition to creativity, something that can be exemplified, teaching creativity is also one of the best and always evolving habits of teaching creative thinking and developing (Henriksen, 2016).

The concept of learning is also in accordance with the principle of a teacher according to Ki Hajar Dewatara namely ing ngarso sung tulodo, ing madyo mbangun karso, tut wuri handayani. Teachers must be able to be role models for their students, be able to build the spirit of students, but also must provide the widest possible opportunity for students to learn further to explore learning resources, elaborate so that students become independent people. Learning because of your own will, so learning does not have to wait to be given, but learns to find and find.

The success of this model improves mathematical problem solving abilities, also due to the obligation of students to produce creative work that is the result of their creative thinking in solving problems. Students are given wide opportunities to discuss with their team, find sufficient information and data and are not limited to the time and place and the role of lecturers directly. This is in accordance with the opinion of Boelens et al., (2017) and research of Wahyudi \& Winanto, A. (2018) learning must be able to stimulate student interaction, facilitate their learning process, and encourage an affective learning climate. Each of their learning activities has been designed and prepared from the beginning and explained to the students the target products that must be produced and how they can meet these targets. So that they in the team will try to meet the predetermined target. 
Student creativity in solving mathematical problems also supported by a learning environment that fosters creativity among students themselves (Soh, 2017, Richardson \& Mishra, 2017). There is an opportunity for each group to present the results in a face-to-face class, thus encouraging other groups to produce better work, and even better. This very positive learning environment triggers students with their teams to continue to improve their creative work. Lecturers in the form of learning simulations by lecturers using animation media, images and even videos of life realities that are close to students so that they are easy to understand also provide positive learning environment. Tsai \& Chung's research (2015) supports that a positive learning environment will make students motivated and creative to produce something useful.

\section{CONCLUSION AND SUGGESTION}

Based on the results of data analysis and discussion, it can be concluded that $3 \mathrm{CM}$ learning with blended learning effectively improves students' problem solving in creative thinking abilities. This happened because learning gives students the opportunity to think systematically by beginning by criticising the interesting contextual problems and ending with meaningful reflection with adequate learning resources both when face-to-face and online. Each of their learning activities has been designed and prepared from the beginning and explained to the students the target products that must be produced and how they can meet these targets. This very positive learning environment triggers students with their teams to continue to improve their creative work. A positive learning environment will make students motivated and creative to produce something useful. The learning must be able to stimulate student interaction, facilitate their learning process, and encourage an affective learning climate.

Based on the results of research and analysis has been conducted on the research results, the suggestions of the results of this study are lecturers are suggested to give their students a great opportunity to develop their creativity in solving mathematical problems. Gives students the opportunity to think systematically by beginning by criticising the interesting contextual problems and ending with meaningful reflection with adequate learning resources both when face-to-face and online.

\section{REFERENCES}

Anthony, G. \& Walshaw, M. (2009). Characteristics of effective teaching of mathematics: A view from the West. Journal of Mathematics Education, 2(2), 147-164.

Boelens, H. (2017). The development of semantic blocking in children. British journal of development psychology, 35(2), 310-315. doi:10.1111/bjdp.12178 .

Henriksen, D. (2016). The seven transdisciplinary habits of minds of creative teachers: An exploratory studi of award winning teachers. Teaching skills and creativity, 22, 212232.doi:10.1016/j.tsc.2016.10.007.

Hersh, R. (1997). What is mathematics, really?. London: Jonathan Cape.

Hsieh, S.W., et.al. (2011). Effects of teaching and learning styles on students' reflection levels for ubiquitous learning. Computers \& education, 57(1), 1194-1201. doi:10.1016/j.compedu.2011.01.004.

Hudojo, H. (1988). Mengajar belajar matematika. Jakarta: Depdikbud Direktorat Jenderal Pendidikan Tinggi Proyek Pengembangan Lembaga Pendidikan Tenaga Kependidikan.

Mann, E. L. (2006). Mathematical creativity and school mathematics: Indicators of mathematical creativity in middle school students 1956. Dissertation abstracts international section a: Humanities and social sciences, 67, 461. Retrieved from: http://www.fisme.science.uu.nl/publicatie s/literatuur/2005_mann_creativity.pdf

Matlin, M. (2009).Cognition (7th ed.). New York: John Wiley \& Sons, Inc.

Morais, M. F., \& Azevedo, I. (2011). What is a creative teacher and what is a creative pupil? Perceptions of teachers. Procedia social and behavioral sciences, 12, 330339. doi:10.1016/j.sbspro.2011.02.042.

Nurhalim, M. S. (2003). Pembinaan kreativitas menuju era global. Bandung: PT Alumni
Rachmawati, I. (2012). Eksplorasi etnomatematika masyarakat Sidoarjo. MATHEdunesa, 1(1). 73-80


Republik Indonesia. (2003). Undang-undang No. 20 tahun 2003 tentang sistem pendidikan nasional. Presiden Republik Indonesia. Jakarta.

Siswono, T. Y. E. (2007). Pembelajaran matematika humanistik yang mengembangkan kreativitas siswa. Yogyakarta: Universitas Sanata Dharma, 1-16.

Soh, K. (2017). Fostering student creativity through teacher behaviors. Thinking Skills and Creativity, 23, 58-66. Retrieved from

https://www.sciencedirect.com/science/art icle/pii/S1871187116301584

Stanny, C.J. (2016). Reevaluating Bloom 's Taxonomy : What measurable verbs can and cannot say about student learning. Retrieved from https://www.mdpi.com/22277102/6/4/37/html

Sternberg. R. J. (2006). The nature of creativity. Creativity research journal, 18(1), 87-98. Retrieved from https://www.tandfonline.com/doi/abs/10.1 207/s15326934crj1801_10

Suarma, D. M., \& Kusumah, Y. S. (2016). Interaksi antara faktor tkam dan pembelajaran terhadap kemampuan penalaran deduktif matematis mahasiswa calon guru SD beserta kinerjanya. Eduhumaniora: Jurnal pendidikan dasar, 4(1). Retrieved from http://ejournal.upi.edu/index.php/eduhum aniora/article/view/2813

Tindowen, D. J. C., Bassig, J. M., \& Cagurangan, J. A. (2017). Twenty-FirstCentury skills of alternative learning system learners. SAGE Open, 7(3), 1-8. doi:10.1177/2158244017726116.

Tsai, C.Y., Horng, J.S., Liu, C.H., Hu, D.C., \& Chung Y.C. (2015). Awakening student creativity: Empirical evidence in a learning environment context. Journal of hospitality, leisure, sport \& tourism education, 17, 28-38. Retrieved from https://www.sciencedirect.com/science/art icle/pii/S1473837615000180

Vale, I. \& Barbosa, A. (2015). Mathematics creativity in elementary teacher training. Journal of the european teacher education network, 10, 101-109. Retrieved from https://jeten-

online.org/index.php/jeten/article/view/70

Wahyudi \& Waluya, B. (2017). The Importance of Cognitive Psychology in Mathematics Learning and Students' Creativity. In Proceeding International Conference on Mathematics, Science, and Education (ICoMSE). Malang State University. Malang. Available at: http://icomse.fmipa.um.ac.id/2017/wpcontent/uploads/2018/10/ProceedingICoMSE-2017-FULL.pdf(Accessed: October 2018).

Wahyudi \& Waluya, B., Rochmad, \& Suyitno, H. (2018). Mathematical Creative Thinking Ability And Scaffolding Process According With Learning Styles For PreService Teachers. Anatolian Journal of Instruction, 3(1), 39-50. Available at: https://onlinelibrary.wiley.com/doi/abs/10 $.1111 /$ bjdp.12178. (Accessed: June 2018).

Wahyudi \& Waluya, B., \& Rochmad. (2018). Scaffolding Based on Learning Style as An Effort to Increase Mathematical Creative Thinking Skill. The International Journal of Research in Teacher Education, 9(1), 34-44. Available at: http://ijrte.penpublishing.net/makale/441. (Accessed: July 2018).

Wahyudi, W., \& Winanto, A. (2018). Development of Project-based Blended Learning (PjB2L) Model To Increase PreService Primary Teacher Creativity. Journal of Educational Science and Technology (EST), 4(2), 91102.

doi:https://doi.org/10.26858/est.v4i2.5563

Wahyudi, Waluya, S. B., \& Suyitno, H. (2018, September). Assimilation and Accommodation Processes in Improving Mathematical Creative Thinking with Scaffolding According to Learning Style. In Journal of Physics: Conference Series (Vol. 1097, No. 1, p. 012156). IOP Publishing. Available at:http://iopscience.iop.org/article/10.108 8/17426596/1097/1/012156/pdf.(Accessed: October 2018). 
Zevenbergen, R., Dole, S., \& Wright, R. J. (2004). Teaching mathematics in primary schools. Crows Nest: Allen \& Unwin. 